\title{
PERTANGGUNGJAWABAN YURIDIS DIREKSI TERHADAP RISIKO KERUGIAN KEUANGAN DAERAH PADA BADAN USAHA MILIK DAERAH
}

\author{
Tengku Erwinsyahbana \\ Fakultas Hukum Universitas Muhammadiyah Sumatera Utara \\ Email: erwin6768@gmail.com
}

\begin{abstract}
Activity which is taken and Regional Owned Enterprises (BUMD) may gives risks, both business risks and criminal implications. As an example taken in relating with a local company in Tanjungpinang City, whose ex-director was complained of a criminal act of corruption for causing financial losses in the management of PT. Tanjungpinang Makmur Bersama. It is interesting to be researched which the nature of the research is descriptive and the type of the is normative juridical with case approach. Based on the results of the analysis can be seen that the financial losses of regions in the implementation of management PT. Tanjungpinang Makmur together in Eva Amalia time as a director, did not meet the elements to be said as criminal act of corruption.
\end{abstract}

\section{Kata Kunci: Badan Usaha Milik Daerah, Direksi, Keuangan Daerah,} Pertanggungjawaban Yuridis

\section{A. Latar Belakang}

Alinea Keempat Pembukaan Undang Undang Dasar Negara Republik Indonesia Tahun 1945 (selanjutnya disebut UUD 1945), mengamanatkan bahwa salah satu tujuan negara adalah untuk memajukan kesejahteraan umum. Sejalan dengan tujuan ini, maka berdasarkan Pasal 33 ayat (2) UUD 1945 ditentukan bahwa cabang-cabang produksi yang penting bagi negara dan yang menguasai hajat hidup orang banyak dikuasai oleh negara. Adanya ketentuan Pasal 33 UUD 1945, membuktikan bahwa secara konstitusional, di Indonesia dianut faham negara kesejahteraan (welfare state). Inti dari istilah welfare state adalah tanggung jawab negara terhadap kesejahteraan warganya (Alfitri, 2012: 454), dengan kata lain bahwa negara kesejahteraan (welfare state) secara singkat didefinisikan sebagai suatu negara yang pemerintahnya dianggap bertanggungjawab dalam menjamin standar kesejahteraan hidup minimum bagi setiap warga negaranya (Oman Sukmana, http://osukmana.blogspot.co.id) dan konsep ini muncul meng- 
gantikan konsep "Legal State" atau "Negara Penjaga Malam" (Ridwan HR, 2006: 14).

Negara merupakan integrasi kekuasaan politik, yang sekaligus sebagai alat (agency) dari masyarakat yang mempunyai kekuasaan untuk mengatur hubunganhubungan manusia dalam masyarakat dan menertibkan gejala-gejala kekuasaan dalam masyarakat. Negara dapat memaksakan kekuasaannya secara sah terhadap semua golongan kekuasaan lainnya dan dapat pula menetapkan tujuan-tujuan dari kehidupan bersama, serta menetapkan cara-cara dan batas-batas kekuasaan dapat digunakan dalam kehidupan bersama, baik oleh individu, golongan atau asosiasi, maupun oleh negara sendiri. Oleh sebab itu, negara dapat mengintegrasikan dan membimbing kegiatan-kegiatan sosial dari penduduknya ke arah tujuan bersama (Oman Sukmana, http://osukmana.blogspot.co.id).

Sesuai dengan penjelasan di atas, maka menurut Miriam Budiardjo dikatakan bahwa negara mempunyai tugas: (1) mengendalikan dan mengatur gejalagejala kekuasaan yang asosial, yakni yang bertentangan satu sama lain, supaya tidak menjadi antagonis yang membahayakan; serta (2) mengorganisir dan mengintegrasikan kegiatan manusia dan golongan-golongan ke arah tercapainya tujuan-tujuan dari masyarakat seluruhnya. Negara menentukan kegiatan-kegiatan asosiasi-asosiasi kemasyarakatan disesuaikan satu sama lain dan diarahkan kepada tujuan nasional. Pengendalian ini dilakukan berdasarkan sistem hukum dan dengan perantaraan pemerintah beserta segala alat perlengkapannya. Kekuasaan negara mempunyai organisasi yang paling kuat dan teratur, oleh sebab itu semua golongan atau asosiasi yang memperjuangkan kekuasaan harus dapat menempatkan diri dalam rangka ini (Miriam Budiardjo, 2008: 48).

Tanggung jawab negara terhadap kehidupan warganya pada masa sekarang sudah semakin kompleks, tugas negara tidaklah hanya terbatas sebagai penjaga tata tertib dan keamanan, tetapi juga bertanggungjawab atas kesejahteraan masyarakatnya. Fungsi negara tidak hanya terbatas sebagai pengatur, pengawas dan pengendali terhadap pasar, tetapi dapat juga berperan sebagai pelaku ekonomi dan pelaku pasar yang secara aktif bertindak melalui Badan Usaha Milik Negara (BUMN) maupun Badan Usaha Milik Daerah (BUMD). Oleh karena itu, 
eksistensi BUMN dan BUMD dalam sebuah welfare state memegang peran yang sangat strategis yang bertugas menjalankan fungsi ganda sebagai agent of development dan social function untuk kesejahteraan masyarakatnya. Fungsi ganda tersebut menyebabkan berbagai aktivitas yang dilakukan BUMN dan BUMD dapat menimbulkan risiko, baik risiko bisnis maupun risiko yang berimplikasi pidana, tetapi dalam artikel ini yang menjadi fokus pembahasan hanya terkait dengan risiko yang terjadi pada BUMD.

Berdasarkan Pasal 304 ayat (1) Undang-undang Nomor 23 Tahun 2014 tentang Pemerintahan Daerah (selanjutnya disingkat UU No. 23 Tahun 2014), ditentukan bahwa daerah dapat melakukan penyertaan modal pada BUMD, sedangkan pada Pasal 1 angka 40 UU No. 23 Tahun 2014, didefenisikan bahwa BUMD adalah badan usaha yang seluruh atau sebagian besar modalnya dimiliki oleh daerah. Terkait dengan BUMD, sampai saat ini hanya diatur dalam Undangundang Nomor 5 Tahun 1962 tentang Perusahaan Daerah (selanjutnya disingkat UU No. 5 Tahun 1962). Berdasarkan Pasal 2 UU No. 5 Tahun 1962 ditentukan bahwa perusahaan daerah ialah semua perusahaan yang didirikan berdasarkan undang-undang ini yang modalnya untuk seluruhnya atau untuk sebagian merupakan kekayaan daerah yang dipisahkan, kecuali jika ditentukan lain dengan atau berdasarkan undang-undang.

Sesuai ketentuan yang terdapat dalam Pasal 4 ayat (1) dan ayat (2) UU No. 5 Tahun 1962, maka Perusahaan Daerah didirikan dengan Peraturan Daerah atas kuasa undang-undang, dan Perusahaan Daerah adalah badan hukum yang kedudukannya sebagai badan hukum diperoleh dengan berlakunya Peraturan Daerah tersebut. Sebagai contoh yang diambil terkait dengan perusahaan daerah ini adalah di Kota Tanjungpinang, yaitu dengan berlakunya Peraturan Daerah Kota Tanjungpinang Nomor 4 Tahun 2007 tentang Badan Usaha Milik Daerah (selanjutnya disingkat Perda No. 4 Tahun 2007). Dalam Perda ini disebutkan bahwa Badan Usaha Milik Daerah yang selanjutnya disingkat BUMD adalah badan usaha yang seluruh atau sebagian besar modalnya berasal dari kekayaan daerah yang dipisahkan (Pasal 1 angka 5). 
Berdasarkan Pasal 2 ayat (2) Perda No. 4 Tahun 2007 ditentukan bahwa BUMD, dapat berbentuk Perusahaan Daerah, Perseroan Terbatas atau badan hukum lainnya. Komposisi modal BUMD dimiliki Pemerintah Daerah seluruhnya atau sekurang-kurangnya $51 \%$ (lima puluh satu persen) yang berasal dari APBD berupa kekayaan daerah yang dipisahkan atau sumber dana yang sah lainnya (Pasal 6 Perda No. 4 Tahun 2007).

Sesuai ketentuan pada Pasal 2 ayat (2) Perda No. 4 Tahun 2007, bahwa BUMD dapat berbentuk perseroan terbatas, maka terhadap BUMD berlaku pula Undang-undang Nomor 40 Tahun 2007 tentang Perseroan Terbatas (selanjutnya disingkat UU No. 40 Tahun 2007), yang berdasarkan Pasal 1 angka 1 disebutkan bahwa: "Perseroan Terbatas, yang selanjutnya disebut Perseroan, adalah badan hukum yang merupakan persekutuan modal, didirikan berdasarkan perjanjian, melakukan kegiatan usaha dengan modal dasar yang seluruhnya terbagi dalam saham dan memenuhi persyaratan yang ditetapkan dalam undang-undang ini serta peraturan pelaksanaannya". Hal ini berarti bahwa dalam BUMD juga terdapat organ perseroan, yang terdiri dari Rapat Umum Pemegang Saham (RUPS), Direksi, dan Dewan Komisaris, dan sesuai pula dengan ketentuan yang terdapat dalam Pasal 8 ayat (1) Perda No. 4 Tahun 2007, yang menentukan bahwa Pengurus BUMD terdiri atas Direksi dan Badan Pengawas atau ditentukan lain oleh peraturan perundang-undangan. Berdasarkan Pasal 1 angka 5 UU No. 40 Tahun 2007, ditentukan bahwa direksi merupakan organ perseroan yang berwenang dan bertanggungjawab penuh atas pengurusan Perseroan untuk kepentingan Perseroan, sesuai dengan maksud dan tujuan Perseroan, serta mewakili Perseroan, baik di dalam maupun di luar pengadilan sesuai dengan ketentuan anggaran dasar.

Adanya ketentuan-ketentuan sebagaimana yang telah diuraikan di atas, memunculkan suatu pertanyaan yang terkait dengan masalah tanggung jawab direksi dalam pengelolaan (menjalankan kepengurusan) BUMD untuk mencari keuntungan, yang modalnya merupakan keuangan negara atau daerah. Apabila dalam pengelolaan dimaksud ternyata BUMD mengalami kerugian (risiko bisnis), padahal direksi telah menjalankannya sesuai dengan anggaran dasar, peraturan 
perundang-undangan dan prinsip-prinsip yang tertuang dalam berbagai peraturan perundang-undangan, maka timbul pertanyaan yang terkait dengan pertanggungjawaban yuridis terhadap kerugian keuangan negara atau daerah. Hal ini tentunya perlu dianalisis melalui suatu penelitian yang berjudul: "Pertanggungjawaban Yuridis Direksi terhadap Risiko Kerugian Keuangan Daerah pada Badan Usaha Milik Daerah", tetapi dibatasi hanya pada BUMD berbentuk Perseroan Terbatas, khususnya dalam kasus perjanjian kerjasama penyertaan modal (investasi) pengadaan tower telekomunikasi pada P.T. Tanjungpinang Makmur Bersama (BUMD Kota Tanjungpinang). Penulis tertarik menganalisis masalah ini karena adanya kasus kerugian keuangan daerah pada P.T. Tanjungpinang Makmur Bersama, yang menyebabkan mantan direksi perusahaan ini telah dilaporkan melakukan tindak pidana korupsi.

\section{B. Metode Penelitian}

Dilihat dari jenisnya, maka penelitian hukum dapat dibedakan menjadi penelitian hukum normatif dan penelitian hukum empiris (Soerjono Soekanto, 2012: 51). Penelitian hukum normatif adalah penelitian terhadap bahan kepustakaan (data sekunder) yang relevan dengan permasalahan yang akan dianalisis, baik berupa bahan hukum primer, bahan hukum sekunder maupun bahan hukum tertier (Soerjono Soekanto dan Sri Mamudji, 2003: 14).

Terkait dengan penelitian normatif, maka ada beberapa pendekatan yang dapat digunakan, yaitu: (1) pendekatan perundang-undangan; (2) pendekatan konsep; (3) pendekatan analitis; (4) pendekatan perbandingan; (5) pendekatan historis; (6) pendekatan filsafat; dan (7) pendekatan kasus (Johny Ibrahim, 2006: 300). Penelitian hukum normatif dengan pendekatan perundang-undangan, berarti fokus penelitiannya adalah terhadap berbagai aturan hukum sebagai tema sentralnya (Johny Ibrahim, 2006: 302), dan berhubung penelitian ini difokuskan untuk menganalisis aturan-aturan hukum (peraturan perundang-undangan) yang berhubungan dengan pertanggungjawaban direksi dalam pengelolaan keuangan daerah sebagai harta kekayaan dari badan usaha milik daerah dalam kasus perjanjian kerjasama penyertaan modal pengadaan tower telekomunikasi pada 
P.T. Tanjungpinang Makmur Bersama (BUMD Kota Tanjungpinang), maka jenis penelitian yang digunakan adalah penelitian hukum normatif dengan pendekatan perundang-undangan dan pendekatan kasus.

Soerjono Soekanto (2012: 50), mengatakan bahwa dari sudut sifatnya, penelitian dapat dibedakan menjadi 3 (tiga) jenis, yaitu: (1) penelitian eksploratoris; (2) penelitian deskriptif; dan (3) penelitian eksplanatoris. Penelitian deskriptif adalah penelitian yang bertujuan untuk memberikan data yang seteliti mungkin tentang manusia, keadaan atau gejala-gejala lainnya (Bambang Sunggono, 1998: 38) dan bertujuan untuk mengungkapkan peraturan perundangundangan yang berkaitan dengan teori-teori hukum yang menjadi objek penelitian (Zainuddin, 2011: 105-106). Berhubung penelitian ini bertujuan untuk memberikan gambaran aturan-aturan hukum tentang pertanggungjawaban direksi dalam pengelolaan keuangan daerah pada badan usaha milik daerah, maka penelitian ini bersifat deskriptif.

Metode pengumpulan data dalam penelitian hukum lazimnya menggunakan metode studi dokumen, pengamatan atau observasi, dan wawancara. Ketiga jenis metode pengumpulan data ini dapat dipergunakan masing-masing, maupun secara bergabung untuk mendapatkan hasil semaksimal mungkin (Soerjono Soekanto, 2012: 66). Berhubung penelitian ini hanya untuk menganalisis data sekunder, maka idealnya hanya menggunakan 1 (satu) metode saja, yaitu metode studi dokumen.

Analisis data dapat digolongkan menjadi 2 (dua) macam, yang meliputi analisis kuantitatif dan analisis kualitatif. Analisis kualitatif merupakan analisis data yang tidak menggunakan angka, melainkan memberikan gambaran-gambaran (deskripsi) dengan kata atas temuan-temuan, dan oleh karena itu lebih mengutamakan mutu (kualitas) dari data, bukan kuantitas, dan dalam penelitian hukum normatif analisis yang digunakan adalah analisis kualitatif (Salim HS dan Erlies Septiana Nurbaini, 2013: 18). Berhubung penelitian ini merupakan penelitian hukum normatif, maka analisis data yang digunakan adalah analisis kualitatif atau lebih tepatnya disebut analisis yuridis kualitatif, karena yang dianalisis adalah informasi yang didapat dari peraturan perundang-undang, serta tulisan-tulisan 
ilmiah dalam bidang hukum (yuridis), khususnya terkait pertanggungjawaban direksi dalam pengelolaan keuangan daerah pada badan usaha milik daerah.

\section{Fakta Yuridis}

Berdasarkan bukti-bukti dan dokumen-dokumen yang ada, dapat dideskripsikan fakta-fakta yuridis, sebagai berikut:

1. Sejak tahun 2012 sampai dengan tahun 2014, Saudari Eva Amalia, menjabat sebagai Direktur pada PT. Tanjungpinang Makmur Bersama (BUMD di Kota Tanjungpinang).

2. Terhitung mulai tanggal 20 Oktober 2011, yakni sejak berlakunya Peraturan Daerah Kota Tanjungpinang Nomor 7 Tahun 2011 tentang Penyertaan Modal Pemerintah Kota Tanjungpinang pada PT. Bank Riau KEPRI, PT. Riau Air Lines, Perusahaan Daerah Bank Perkreditan Rakyat Bestari, dan PT. Tanjungpinang Makmur Bersama, maka berdasarkan Pasal 8 Peraturan Daerah ini, ditentukan bahwa:

Ayat (1) Penyertaan Modal Pemerintah Kota dalam bentuk uang yang dipergunakan untuk pembelian sertifikat saham pada PT. Tanjungpinang Makmur Bersama sebesar Rp. 10.000.000.000.(sepuluh milyar rupiah) sampai dengan tahun 2015;

Ayat (2) Penyertaan Modal Pemerintah Kota pada PT. Tanjungpinang Makmur Bersama sampai dengan 31 Desember 2010 adalah sebesar Rp. 1.598.000.000.- (satu milyar lima ratus sembilan puluh delapan juta rupiah);

Ayat (3) Sisa kurang Penyertaan Modal Pemerintah Kota pada PT. Tanjungpinang Makmur Bersama sebesar Rp. 8.402.000.000,(delapan milyar empat ratus dua juta rupiah) akan dipenuhi selambatlambatnya tahun anggaran 2015; dan

Ayat (4) Penyertaan modal Pemerintah Kota dalam bentuk barang bergerak dan tidak bergerak pada PT. Tanjungpinang Makmur Bersama sampai dengan 31 Desember 2010 adalah sebagaimana tercantum dalam Lampiran II, yang merupakan bagian yang tidak terpisahkan dari Peraturan Daerah ini.

3. Terhitung sejak tahun 2010 sampai dengan tahun 2015 , penyertaan modal Pemerintah Kota Tanjungpinang pada PT. Tanjungpinang Makmur Bersama (BUMD di Kota Tanjungpinang) adalah sebesar Rp. 6.600.000.000,- (enam milyar enam ratus juta rupiah), dengan perincian sebagai berikut: 
Tabel 1:

\section{Penyertaan Modal Pemerintah Kota Tanjungpinang pada PT. Tanjungpinang Makmur Bersama Tahun 2010 s.d Tahun 2015}

\begin{tabular}{llll}
\hline Tahun & Masa Jabatan & Nilai Penyertaan Modal \\
\hline 2010 & Plt. Direktur & : Marzul Henri & Rp. $1.600 .000 .000,-$ \\
2012 & Direktur & : Eva Amalia & Rp. $2.500 .000 .000,-$ \\
2015 & Direktur Utama: Asep Nana S. & Rp. $2.500 .000 .000,-$ \\
\hline Total & & Rp. $6.600 .000 .000,-$ \\
\hline
\end{tabular}

4. Berdasarkan data sebagaimana tersebut pada angka 3 di atas, maka penyertaan modal Pemerintah Kota Tanjungpinang pada PT. Tanjungpinang Makmur Bersama (BUMD di Kota Tanjungpinang) dalam masa jabatan Eva Amalia sebagai Direktur, yaitu sejak tahun 2012 sampai dengan tahun 2014, adalah sebesar Rp. 2.500.000.000,- (dua milyar lima ratus juta rupiah).

5. Peruntukan penyertaan modal sebagaimana tersebut pada angka 4 di atas, diajukan sesuai dengan Rencana PT. Tanjungpinang Makmur Bersama (BUMD di Kota Tanjungpinang) tahun 2011-2015 dan disampaikan kepada Pemegang Saham PT. Tanjungpinang Makmur Bersama (BUMD di Kota Tanjungpinang) dalam Rapat Umum Pemegang Saham (RUPS), Tahun 2011 yang dilaksanakan pada tanggal 26 Juni 2012 (Tahap 1) dan tanggal 16 Desember 2012 (Tahap 2).

6. Tahun 2012 dalam masa jabatan Eva Amalia sebagai Direktur PT. Tanjungpinang Makmur Bersama (BUMD di Kota Tanjungpinang), dimulai inisiatif pengembangan usaha dengan menggandeng mitra dalam bidang penyediaan dan operasional pembangunan pertelekomunikasian Kota Tanjungpinang, yaitu PT. Gametraco Tunggal yang merupakan perusahaan Tower Provider (TP) yang telah memiliki track record yang cukup baik dengan total hampir 200 tower (tahun 2012) dan saat ini telah mencapai 600 tower, dan PT. Gametraco Tunggal menyampaikan bahwa market (pasar) pengguna layanan selular untuk provider Telkomsel dan XL untuk Kota Tanjungpinang sebagai ibukota provinsi masih sangat menjanjikan. 
7. Dasar dan pertimbangan kerjasama PT. Tanjungpinang Makmur Bersama (BUMD di Kota Tanjungpinang) dengan PT. Gametraco Tunggal, terkait pengembangan bidang usaha pertelekomunikasian, yaitu:

a. perkembangan teknologi informasi di bidang telekomunikasi, dan gencarnya provider selular dengan market (pasar) yang semakin meningkat;

b. kedudukan strategis Kota Tanjungpinang selaku ibukota Provinsi Kepulauan Riau dengan target market (pasar) pengguna layanan selular telekomunikasi yang cukup tinggi;

c. banyaknya tower-tower yang berdiri tanpa memiliki IMB di Tanjungpinang, sehingga PT. Tanjungpinang Makmur Bersama (BUMD di Kota Tanjungpinang) dapat berperan sebagai center of coordination untuk pembangunan dan pengembangan menara telekomunikasi terpadu di Tanjungpinang;

d. benchmark Pekanbaru (Provinsi Riau) dan Padang (Provinsi Sumatera Barat) di wilayah Sumatera, merupakan basis bisnis mitra, baik PT. Gametraco Tunggal maupun PT. Lintas Media Asia;

e. Penguatan posisi PT. Tanjungpinang Makmur Bersama (BUMD di Kota Tanjungpinang) sesuai dengan Peraturan Daerah Kota Tanjungpinang Nomor 4 Tahun 2007 tentang Badan Usaha Milik Daerah dan Peraturan Daerah Kota Tanjungpinang Nomor 7 Tahun 2011 tentang Penyertaan Modal Pemerintah Kota Tanjungpinang pada PT. Bank Riau KEPRI, PT. Riau Air Lines, Perusahaan Daerah Bank Perkreditan Rakyat Bestari, dan PT. Tanjungpinang Makmur Bersama; dan

f. kemitraan yang dibina PT. Tanjungpinang Makmur Bersama (BUMD di Kota Tanjungpinang) dengan perusahaan skala nasional di bidang telekomunikasi, merupakan investasi jangka menengah dan jangka panjang, dengan keuntungan portofolio bagi perusahaan PT. Tanjungpinang Makmur Bersama (BUMD di Kota Tanjungpinang).

8. Rencana perjanjian kerjasama antara PT. Tanjungpinang Makmur Bersama (BUMD di Kota Tanjungpinang) dengan PT. Gametraco Tunggal tersebut, 
sebelumnya telah disampaikan secara tertulis kepada Walikota Tanjungpinang selaku Pemegang Saham pada PT. Tanjungpinang Makmur Bersama (BUMD di Kota Tanjungpinang) dan Dewan Komisaris PT. Tanjungpinang Makmur Bersama (BUMD di Kota Tanjungpinang), melalui Surat Ref. No.: 87/DirTMB/III/2012, tertanggal 17 Maret 2012, tentang Kemitraan StrategisRencana Kerjasama Menara Telekomunikasi Terpadu dengan PT. Gametraco Tunggal, yang memuat: (a) latar belakang rencana investasi yang dikerjasamakan dengan PT. Gametraco Tunggal; dan (b) maksud dan tujuan kerjasama agar PT. Tanjungpinang Makmur Bersama (BUMD di Kota Tanjungpinang) memiliki usaha di bidang strategis.

9. Rencana perjanjian kerjasama sebagaimana tertuang dalam Surat Ref. No: 87/Dir-TMB/III/2012, tertanggal 17 Maret 2012 tersebut di atas, ditindaklanjuti melalui Surat Ref. No.: 117/Dir-TMB/IV/2012, tertanggal 19 April 2012 dan Surat Ref. No.: 159/Dir-TMB/V/2012, tertanggal 31 Mei 2012, untuk mendapatkan persetujuan pada pelaksanaan Rapat Umum Pemegang Saham (RUPS) PT. Tanjungpinang Makmur Bersama (BUMD di Kota Tanjungpinang) tertanggal 26 Juni 2012.

10. Pada risalah Rapat Umum Pemegang Saham (RUPS) Tahun 2011 tersebut, antara lain dinyatakan:

a. penyesuaian modal yang disetor menjadi Rp. 4.100.000.000,- (empat milyar seratus juta rupiah) dan meningkatkan Modal Dasar Perseroan berupa barang bergerak dan barang tidak bergerak sebesar Rp. 16.493.345.405,- (enam belas milyar empat ratus sembilan puluh tiga juta tiga ratus empat puluh lima empat ratus lima rupiah); dan

b. persetujuan rencana investasi tahun 2012 terkait pembangunan menara (tower) terpadu Tahap I kerjasama dengan PT. Gametraco Tunggal dan Tahap II kerjasama dengan PT. Lintas Media Asia.

11. Antara PT. Tanjungpinang Makmur Bersama (BUMD di Kota Tanjungpinang) dan PT. Gametraco Tunggal ditindaklanjuti dengan penandatanganan Nota Kesepahaman (MOU) pada tanggal 12 Juni 2012, diketahui dan ditandatangani oleh Komisaris PT. Tanjungpinang Makmur 
Bersama (BUMD Kota Tanjungpinang) dan Komisaris PT. Gametraco Tunggal, yang ditindaklanjuti dengan Perjanjian Kerjasama Pengelolaan Potensi Telekomunikasi, Informasi, dan Teknologi (ICT) dengan PT. Gametraco Tunggal Nomor: 010/PKS/PT.TMB-VII /2012, tertanggal 9 Juli 2013.

12. Setelah penandatangan Nota Kesepahaman $(M O U)$ sebagaimana tersebut pada angka 11 di atas, maka dilaksanakan pertemuan koordinasi dengan mitra berdasarkan rencana cell plan Kota Tanjungpinang, yang mengacu kepada Rencana Tata Ruang kota Tanjungpinang, dan selanjutnya dilakukan join survey untuk pengajuan site/lokasi (coordinate location) kepada provider. Penentuan site/lokasi (coordinate location), ditentukan berdasarkan survey yang dilaksanakan oleh Tower Provider (TP), yakni mitra PT. Gametraco Tunggal dan lokasi diputuskan/ditentukan oleh provider komunikasi, yakni TELKOMSEL dan XL.

13. Mengingat adanya kendala ketiadaan sumberdaya manusia (tenaga ahli) pada PT. Tanjungpinang Makmur Bersama (BUMD Kota Tanjungpinang) untuk pelaksanaan survey dan SITAC (site aqcusition), maka berdasarkan hasil kesepakatan dengan PT. Gametraco Tunggal, Saudara Teddy DSP (mewakili PT. Gametraco Tunggal telah merekomendasikan penempatan 1 (satu) orang tenaga SITAC, bernama Jimmi Marbun, dan PT. Tanjungpinang Makmur Bersama (BUMD Kota Tanjungpinang) mengeluarkan SPK kepada Jimmi Marbun, untuk pelaksanaan SITAC.

14. Mekanisme biaya-biaya yang dikeluarkan terkait dengan pekerjaan SITAC, terdiri dari:

a. Untuk harga sewa lahan dipakai patokan kepatutan harga sewa yang menjadi acuan untuk sewa lahan serupa bagi penempatan tower dengan kategori greenfield (di atas tanah) atau disebut dengan tower makro atau kategori rooftop (di atas bangunan); dan

b. Untuk pembayaran sewa lahan, sebagai berikut: 
1) estimasi penentuan nilai harga sewa untuk lahan untuk lokasi dimaksud berdasarkan acuan harga sewa untuk kategori jenis tower yang akan dibangun;

2) acuan harga yang dipakai berdasarkan kepatutan pada nilai sewa di lokasi/ daerah lain, seperti di Pekanbaru, Padang dan Batam;

3) pembayaran sewa lahan dilaksanakan secara bertahap dan pembayaran sewa lahan dilakukan dengan cara transfer ke rekening yang pemilik lahan atau kuasanya atau melalui cek tunai yang dikeluarkan sesuai dengan besaran jumlah sewa lahan yang dibayarkan; dan

4) Biaya SITAC yang meliputi Ijin Warga, Ijin lingkungan RT/RW hingga Lurah dan Camat, serta biaya pengurusan rekomendasi untuk pengurusan IMB adalah menjadi tanggungjawab PT. Tanjungpinang Makmur Bersama (BUMD Kota Tanjungpinang).

15. Jumlah biaya (investasi) dalam pelaksanaan perjanjian kerjasama pembangunan tower sebagaimana diuraikan di atas dalam kurun waktu tahun 2012 sampai dengan tahun 2014, yakni pada masa Saudari Eva Amalia masih menjabat sebagai Direktur PT. Tanjungpinang Makmur Bersama (BUMD di Kota Tanjungpinang), adalah sebesar Rp. 1.046.013.800,- (satu milyar empat puluh enam juta tiga belas ribu delapan ratus rupiah, dengan perincian sebagai berikut:

Tabel 2:

Investasi Pelaksanaan Perjanjian Kerjasama Pembangunan Tower Tahun 2012 s.d. Tahun 2014

\begin{tabular}{lc}
\hline Tahun & Jumlah Biaya Investasi Tower \\
\hline 2012 & $529.434 .200,-$ \\
2013 & $471.279 .600,-$ \\
2014 & $45.300 .000,-$ \\
\hline Total & $1.046 .013 .800,-$ \\
\hline
\end{tabular}

16. Dalam pelaksanaan pekerjaan SITAC, ternyata Jimmi Marbun tidak dapat mempertanggungjawabkan beberapa realisasi biaya pengeluaran seperti tersebut di atas dan hal ini sudah disampaikan kepada pihak mitra (yakni PT. Gametraco Tunggal), sedangkan untuk biaya-biaya yang dikeluarkan tersebut, 
telah diperhitungkan dan tetap menjadi kewajiban dari PT. Gametraco Tunggal untuk direimburse ke PT. Tanjungpinang Makmur Bersama (BUMD di Kota Tanjungpinang).

17. Dalam pelaksanaan perjanjian kerjasama sebagaimana tersebut di atas, terdapat kendala-kendala internal perusahaan pada PT. Tanjungpinang Makmur Bersama (BUMD di Kota Tanjungpinang), yaitu:

a. pada tahun 2014, terdapat kebijakan manajemen PT. Tanjungpinang Makmur Bersama (BUMD Kota Tanjungpinang) dari Dewan Komisaris terhadap kelanjutan investasi dan kerjasama, mengingat belum adanya pengembalian pembiayaan dan pola sharing yang disepakati;

b. pergantian Direktur pada bulan September 2014 dan masa peralihan/ transisi Plt Direktur, yang menjabat hingga September 2015 pada PT. Tanjungpinang Makmur Bersama (BUMD Kota Tanjungpinang), sehingga keputusan strategis terhadap tindak lanjut kerjasama belum dapat direalisasikan;

c. Keputusan Rapat Umum Pemegang Saham (RUPS) Luar Biasa yang dilaksanakan pada bulan September 2015 memerintahkan Direksi untuk konsentrasi terhadap pengembalian (reimbursement) pembiayaan yang sudah keluar untuk kerjasama ini, dan pengembalian pembiayaan tersebut telah diupayakan melalui tindak lanjut koordinasi dan konsolidasi dengan mitra PT. Gametraco Tunggal yang dilakukan dengan penyiapan berkas dan dokumen mulai dari SITAC (Site Acquisition), Ijin Warga dan proses perijinan untuk site yang telah diselesaikan prosesnya, yakni: Site Kampung Bugis, Site Tanjung Keriting Tengah dan Site Bukit Tanjungpinang (Pelindo);

d. Terdapat kebijakan yang lebih ketat terhadap persyaratan pengeluaran IMB (Ijin Mendirikan Bangunan) dari Pemerintah Kota Tanjungpinang pada tahun 2013, sehingga beberapa persyaratan yang dimiliki untuk pengurusan IMB tower-tower tersebut mengalami kendala waktu penyelesaian; 
e. Adanya kendala tenaga (sumber daya manusia) di lapangan dalam pengurusan SITAC (Site Acqusition) dan perijinan lainnya; dan

f. Kerjasama baru disetujui untuk dilaksanakan dan ditindaklanjuti kembali setelah pelaksanaan Rapat Umum Pemegang Saham (RUPS) Tahun 2016 yang dilaksanakan oleh Direksi masa jabatan 2015-2018

18. Selain kendala-kendala internal yang disebutkan di atas, keberlanjutan perjanjian kerjasama antara PT. Tanjungpinang Makmur Bersama (BUMD Kota Tanjungpinang) dengan PT. Gametraco Tunggal dan PT. Lintas Media Asia pada tahun 2013 belum diselesaikan, karena terdapat kendala-kendala eksternal, sebagai berikut:

a. adanya permasalahan internal personal (individu) Person in Charge (PIC) Kuasa/ Perwakilan PT. Gametraco Tunggal (Saudara Teddy DSP), yang melakukan tindakan hukum illegal, yakni mengatasnamakan PT. Gametraco Tunggal sekaligus memperkenalkan dan membawa PT. Lintas Media Asia sebagai bagian (anak perusahaan) dari PT. Gametraco Tunggal, yang menyebabkan Saudara Teddy DSP diberhentikan dari perusahaan PT. Gametraco Tunggal, dan hal ini baru diketahui setelah pihak manajemen perusahaan PT. Gametraco Tunggal mengadakan pertemuan dengan pihak manajemen perusahaan PT. Tanjungpinang Makmur Bersama (BUMD Kota Tanjungpinang), yang menyimpulkan dan memutuskan perbuatan hukum yang dilakukan Saudara Teddy DSP, tidak dapat lagi dipertanggungjawabkan sebagai perwakilan PT. Gametraco Tunggal;

b. terjadi perubahan teknologi terkait dengan pembangunan dan pengembangan menara telekomunikasi berbentuk makro, baik greenfield dan monopole seiring dengan perkembangan teknologi beralih kepada teknologi BTS Hotel, sehingga beberapa titik/site yang sudah di plot sebelumnya belum dapat dilaksanakan; dan

c. adanya downturn provider telekomunikasi XL pada tahun 2013-2014 untuk penambahan tower makro, sehingga ada kendala teknis terhadap titik/site yang sudah di plot sebelumnya; 
19. Pada kurun waktu tahun 2014 sampai dengan tahun 2015, mantan Direktur PT. Tanjungpinang Makmur Bersama (BUMD Kota Tanjungpinang), yang dalam hal ini Saudara Eva Amalia, dengan itikad baik tetap melakukan koordinasi dan konsolidasi dengan Dewan Direksi dan Komisaris PT. Tanjungpinang Makmur Bersama (BUMD Kota Tanjungpinang), antara lain:

a. Koordinasi dan konsolidasi dengan Plt. Direktur (Saudara Yuswandi), guna menindaklanjuti temuan LHP Inspektorat dan BPKP Nomor: 04/LHATT/ITKO.JA/VIII/ 2015, terkait dengan pengembalian biaya yang telah dikeluarkan untuk dilakukan penagihan sampai dengan tahun 2014), baik yang bekerjasama dengan PT. Gametraco Tunggal maupun dengan PT. Lintas Media;

b. Mengadakan Rapat pendahuluan Direktur Utama PT. Tanjungpinang Makmur Bersama (BUMD Kota Tanjungpinang) dengan mitra PT. Gametraco Tunggal di Jakarta, pada tanggal 26 September 2015; dan

c. Penentuan site visit PT. Gametraco Tunggal untuk titik ulang site SITAC dan relokasi site BTS/microcell, pada tanggal 6 dan 7 Oktober 2015.

\section{Analisis}

Berdasarkan fakta yuridis yang diuraikan di atas dan berikut dengan merujuk pada peraturan perundang-undangan terkait, maka dapat diketahui bahwa PT. Tanjungpinang Makmur Bersama merupakan badan hukum yang dibentuk berdasarkan Peraturan Daerah Kota Tanjungpinang Nomor 4 Tahun 2007 tentang Badan Usaha Milik Daerah, dan sesuai ketentuan yang terdapat dalam Pasal 6 Peraturan Daerah ini, maka komposisi modalnya dimiliki oleh Pemerintah Daerah (dalam hal ini Pemerintah Kota Tanjungpinang) untuk seluruhnya atau sekurangkurangnya $51 \%$ (lima puluh satu persen) yang berasal dari APBD Kota Tanjungpinang berupa kekayaan daerah yang dipisahkan atau sumber dana yang sah lainnya. Berhubung badan hukum ini berbentuk Perseroan, maka kepadanya juga berlaku ketentuan yang terdapat dalam Undang-undang Nomor 40 Tahun 2007 tentang Perseroan Terbatas. 
Kepemilikan modal Pemerintah Kota Tanjung Pinang pada PT. Tanjungpinang Makmur Bersama adalah sah secara yuridis, karena didasarkan pada Peraturan Daerah Kota Tanjungpinang Nomor 7 Tahun 2011 tentang Penyertaan Modal Pemerintah Kota Tanjungpinang pada PT. Bank Riau KEPRI, PT. Riau Air Lines, Perusahaan Daerah Bank Perkreditan Rakyat Bestari, dan PT. Tanjungpinang Makmur Bersama, dan berdasarkan Pasal 8 Peraturan Daerah Kota Tanjungpinang ini ditentukan bahwa penyertaan modal Pemerintah Kota dalam bentuk uang yang dipergunakan untuk pembelian sertifikat saham pada PT. Tanjungpinang Makmur Bersama sebesar Rp. 10.000.000.000.- (sepuluh milyar rupiah) sampai dengan tahun 2015, yang penyerahannya dilakukan secara bertahap, yaitu sebesar Rp. 1.598.000.000.- (satu milyar lima ratus sembilan puluh delapan juta rupiah) pada tanggal 31 Desember 2010 dan sebesar Rp. 8.402.000.000,- (delapan milyar empat ratus dua juta rupiah) dipenuhi selambatlambatnya tahun anggaran 2015. Atas dasar ini, dapat diketahui bahwa kepemilikan saham Pemerintah Kota Tanjung Pinang pada PT. Tanjungpinang Makmur Bersama adalah sebesar Rp. 10.000.000.000.- (sepuluh milyar rupiah).

Saham yang dimiliki Pemerintah Kota Tanjung Pinang pada PT. Tanjungpinang Makmur Bersama dikelola untuk pembangunan (pengadaan) tower jaringan telekomunikasi, yang dilakukan melalui perjanjian kerjasama dengan perusahaan PT. Gametraco Tunggal dan PT. Lintas Media, yang perjanjian ini tentunya tunduk pada ketentuan yang terdapat dalam Kitab Undangundang Hukum Perdatan (KUH Perdata), dengan kata lain bahwa perjanjian kerjasama pembangunan (pengadaan) tower jaringan telekomunikasi antara PT. Tanjungpinang Makmur Bersama dengan PT. Gametraco Tunggal dan PT. Lintas Media, merupakan perbuatan yang terletak dalam hukum privaat (perdata), dan sesuai dengan asas hukum perjanjian sebagaimana tertuang dalam Pasal 1338 KUHP Perdata, bahwa semua perjanjian yang dibuat secara sah mengikat sebagai undangan-undang bagi para pihak (yang dalam hal ini adalah PT. Tanjungpinang Makmur Bersama dan PT Gametraco Tunggal, serta PT. Lintas Media).

Dalam pelaksanaan perjanjian, dapat saja isi perjanjian tersebut (prestasi) tidak dapat dilaksanakan, baik karena sengaja atau lalai ada pihak yang 
melakukan wanprestasi atau karena suatu keadaan memaksa di luar kehendak para pihak, yang dalam lapangan hukum perdata dikenal dengan istilah overmacht (keadaan memaksa), yaitu suatu keadaan dimana debitor tidak dapat melakukan prestasinya kepada kreditor setelah di buatnya persetujuan, yang menghalangi debitor untuk memenuhi prestasinya, dan debitor tidak dapat dipersalahkan serta tidak harus menanggung risiko, karena tidak dapat menduga pada waktu persetujuan dibuat yang disebabkan adanya kejadian yang berbeda di luar kuasanya, seperti: gempa bumi, banjir dan kecelakaan.

Dalam KUH Perdata, masalah overmacht atau keadaan memaksa diatur dalam Buku III Pasal 1244 dan 1245, yang menentukan bahwa:

1. Debitor harus dihukum untuk mengganti biaya, kerugian dan bunga, bila ia tak dapat membuktikan bahwa tidak dilaksanakannya perikatan itu atau tidak tepatnya waktu dalam melaksanakan perikatan itu disebabkan oleh sesuatu hal yang tidak terduga, yang tidak dapat dipertanggungkan kepadanya, walaupun tidak ada itikad buruk kepadanya.

2. Tidak ada penggantian biaya, kerugian dan bunga, bila karena keadaan memaksa atau karena hal yang terjadi secara kebetulan, debitor terhalang untuk memberikan atau berbuat sesuatu yang diwajibkan, atau melakukan suatu perbuatan yang terlarang baginya.

Memperhatikan kedua ketentuan tersebut di atas, maka terdapat 3 (tiga) unsur yang harus dipenuhi dalam overmacht (keadaan memaksa), yakni:

1. debitor tidak memenuhi prestasi walaupun telah berusaha secara patut;

2. ada sebab yang terletak diluar kesalahan debitor; dan

3. faktor penyebab itu tidak dapat diduga oleh siapapun dan tidak dapat dipertanggungjawabkan kepada debitor.

Keadaan memaksa (overmacht), dibedakan dalam 2 (dua) jenis, yang dapat dijelaskan sebagai berikut:

1. Keadaan memaksa absolut, yaitu suatu keadaan dimana debitor sama sekali tidak dapat memenuhi perutangannya kepada kreditor, karena adanya gempa bumi, banjir bandang, dan adanya lahar. Contohnya, si A ingin membayar utangnya pada si $\mathrm{B}$, tetapi tiba-tiba pada saat si $\mathrm{A}$ ingin melakukan 
pembayaran utang, terjadi gempa bumi, maka si A sama sekali tidak dapat membayar utangnya pada si B. Keadaan memaksa mengakibatkan, bahwa suatu hak atau kewajiban dalam perhubungan hukum sama sekali tidak dapat dilaksanakan oleh siapapun juga dan bagaimanapun juga, maka keadaan memaksa itu dinamakan "absolut". Keadaan memaksa yang bersifat mutlak (absolut) yaitu dalam halnya sama sekali tidak mungkin lagi melaksanakan perjanjiannya (misalnya barangnya sudah hapus karena bencana alam).

2. Keadaan memaksa relatif, yaitu suatu keadaan yang menyebabkan debitor masih mungkin untuk melaksanakan prestasinya, tetapi pelaksanaan prestasi itu harus dilakukan dengan memberikan korban yang besar yang tidak seimbang atau menggunakan kekuatan jiwa yang di luar kemampuan manusia atau kemungkinan tertimpa bahaya kerugian yang sangat besar. Contohnya: A telah meminjam atau kredit usaha tani dari KUD, dengan janji akan dibayar pada musim panen, tetapi sebelum panen, padinya diserang oleh hama. Dengan demikian, pada saat itu ia tidak mampu membayar kredit usaha taninya kepada KUD, tetapi ia akan membayar pada musim panen mendatang. Keadaan memaksa dinamakan "relatif", apabila keadaan itu yang pelaksanaan hak-hak dan kewajiban-kewajiban pada suatu perhubungan hukum tidak dapat dihilangkan sama sekali, dan tidak dapat terjadi dalam keadaan bagaimanapun juga, tetapi demikian sukarnya dan dengan pengorbanan dari yang harus melaksanakan, sedemikian rupa, sehingga patutlah, bahwa keharusan untuk melaksanakan hak-hak dan kewajiban-kewajiban yang bersangkutan dianggap lenyap. Adanya keadaan memaksa yang relatif ini, sangat tergantung dari pada isi, maksud, dan tujuan dari perhubungan hukum yang bersangkutan. Misalnya, seorang tukang berjanji akan membangun rumah untuk orang lain, kemudian pada waktu pembangunan rumah itu sedang berjalan segenap buruh-buruhnya bersama-sama mogok. Apakah karena keadaan ini keharusan untuk menyelesaikan pembangunan rumah adalah lenyap? Tukang pembangun rumah harus mempekerjakan lain-lain buruh, bagaimanapun mahalnya upah buruh-buruh itu, maka dalam hal ini dapat dikatakan tidak ada keadaan memaksa, tetapi jika berhubungan dengan isi, maksud, dan tujuan 
dari perjanjian antara kedua belah pihak, dapat dikatakan bahwa pengorbanan yang sedemikian besarnya, tidak patut dibebankan kepada si tukang pembangun rumah, dan hal ini adalah keadaan memaksa dalam arti relatif.

Memperhatikan fakta yuridis perjanjian kerjasama penyertaan modal (investasi) pengadaan tower telekomunikasi pada P.T. Tanjungpinang Makmur Bersama (BUMD Kota Tanjungpinang) di tahun 2012-2014, sesungguhnya merupakan perbuatan hukum dan hubungan hukum yang terletak dalam lapangan hukum privaat (perdata), maka dapat dikatakan bahwa tidak terlaksana isi perjanjian yang dimaksud terjadi karena adanya keadaan memaksa (overmacht), sehingga berlakulah ketentuan yang terdapat dalam Pasal 1244 dan 1245 KUH Perdata. Adapun keadaan memaksa (overmacht) dimaksudkan termasuk dalam kategori (jenis) keadaan memaksa yang relatif, karena tidak terlaksananya perjanjian kerjasama penyertaan modal (investasi) pengadaan tower telekomunikasi pada P.T. Tanjungpinang Makmur Bersama (BUMD Kota Tanjungpinang) di tahun 2012-2014, tidak karena kesalahan atau kelalaian pada pihak P.T. Tanjungpinang Makmur Bersama (BUMD Kota Tanjungpinang), melainkan karena adanya kendala internal dan eksternal sebagaimana dijelaskan sebelumnya.

Mengingat kedudukan atau jabatan Saudara Eva Amalia sebagai Direktur pada P.T. Tanjungpinang Makmur Bersama (BUMD Kota Tanjungpinang) tahun 2012 sampai dengan tahun 2014, maka perlu pula diperhatikan doktrin fiduciary duty dan doktrin business judgment rule.

Doktrin fiduciary duty merupakan salah satu areal terpenting (ring satu) dalam hukum perseroan, berasal dan mempunyai akar-akarnya dalam dalam hukum romawi, tetapi banyak dikembangkan dalam sistem hukum Anglo Saxon, yang menyelusup ke dalam berbagai bidang hukum, termasuk ke dalam hukum perusahaan dengan mengintrodusirnya sebagai tugas fiduciary dari direksi. Tugas fiduciary duty merupakan sebuah amanah di pundak direksi. Berdasarkan arti dari kata fiduciary yang berarti kepercayaan, maka direksi memegang kepercayaan yang diberikan kepadanya oleh perusahaan, dan dengan amanah fiduciary, maka direksi wajib dengan itikad baik menjalankan tugasnya dan fungsinya, yaitu 
dalam fungsi manajemen dan fungsi representasi. Doktrin fiduciary duty ini di atur dalam Pasal 92 ayat (1) Undang-undang Nomor 40 Tahun 2007 tentang Perseroan Terbatas, yang menentukan bahwa direksi menjalankan pengurusan Perseroan untuk kepentingan Perseroan dan sesuai dengan maksud dan tujuan Perseroan.

Doktrin business judgment rule merupakan doktrin yang melindungi direksi atas setiap keputusan bisnis yang merupakan transaksi perseroan, selama hal tersebut dilakukan dalam batas-batas kewenangan dengan penuh kehati-hatian dan itikad baik. Doktrin business judgment rule adalah suatu prinsip hukum yang berasal dari sistem common law dan merupakan derivative dari Hukum Korporasi di Amerika Serikat. Konsep ini mencegah pengadilan-pengadilan di Amerika Serikat untuk mempertanyakan pengambilan keputusan usaha oleh Direksi, yang diambil dengan itikad baik. Pada umumnya prinsip ini telah dianut dalam dunia bisnis di Indonesia dan hal tersebut disebutkan secara eksplisit dalam Pasal 97 Undang-undang Nomor 40 Tahun 2007 tentang Perseroan Terbatas, yang antara lain menentukan bahwa direksi bertanggungjawab atas pengurusan Perseroan, dan pengurusan wajib dilaksanakan setiap anggota direksi dengan itikad baik dan penuh tanggung jawab.

Memperhatikan kedua doktrin tersebut di atas serta fakta yuridis dalam pelaksanaan perjanjian kerjasama penyertaan modal (investasi) pengadaan tower telekomunikasi pada P.T. Tanjungpinang Makmur Bersama (BUMD Kota Tanjungpinang) di tahun 2012-2014, maka Saudara Eva Amalia, sesungguhnya tidak dapat untuk dimintai pertanggungjawaban karena kesalahan atau kelalaiannya menyebabkan terkendalanya pelaksanaan perjanjian kerjasama dimaksud.

Terkait dengan unsur tindak pidana korupsi sebagaimana di atur dalam Undang-undang Nomor 31 Republik Indonesia tentang Pemberantasan Tindak Pidana Korupsi yang telah diubah dengan Undang-undang Nomor 20 Tahun 2001 tentang Perubahan Atas Undang-undang Nomor 31 Tahun 1999 tentang Pemberantasan Tindak Pidana Korupsi, maka yang perlu diperhatikan adalah Pasal 2 ayat (1) dan Pasal 3, menentukan bahwa: 
1. setiap orang yang secara melawan hukum melakukan perbuatan memperkaya diri sendiri atau orang lain atau suatu korporasi yang dapat merugikan keuangan negara atau perekonomian negara, dipidana dengan pidana penjara seumur hidup atau pidana penjara paling singkat 4 (empat) tahun dan paling lama 20 (dua puluh) tahun dan denda paling sedikit Rp. 200.000.000,00 (dua ratus juta rupiah) dan paling banyak Rp. 1.000.000.000,00 (satu miliar rupiah); dan

2. setiap orang yang dengan tujuan menguntungkan diri sendiri atau orang lain atau suatu korporasi, menyalahgunakan kewenangan, kesempatan atau sarana yang ada padanya karena jabatan atau kedudukan yang dapat merugikan keuangan negara atau perekonomian negara, dipidana dengan pidana penjara seumur hidup atau pidana penjara paling singkat 1 (satu) tahun dan paling lama 20 dua puluh) tahun dan atau denda paling sedikit Rp. 50.000.000,00 (lima puluh juta rupiah) dan paling banyak Rp. 1.000.000.000,00 (satu miliar rupiah).

Kalimat "secara melawan hukum melakukan perbuatan memperkaya diri sendiri atau orang lain atau suatu korporasi” yang terdapat pada Pasal 2 ayat (1) dan kalimat "tujuan menguntungkan diri sendiri atau orang lain atau suatu korporasi, menyalahgunakan kewenangan, kesempatan atau sarana yang ada padanya karena jabatan atau kedudukan" yang terdapat pada Pasal 3, merupakan salah satu unsur yang harus dipenuhi untuk disebut sebagai perbuatan yang termasuk sebagai tindak pidana korupsi. Memperhatikan fakta yuridis sebagaimana dijelaskan $\mathrm{di}$ atas, tidak terlaksananya perjanjian kerjasama penyertaan modal (investasi) pengadaan tower telekomunikasi pada P.T. Tanjungpinang Makmur Bersama (BUMD Kota Tanjungpinang) di tahun 20122014 adalah karena adanya kendala internal dan kendala eksternal, sama sekali tidak dapat dikatakan sebagai tindakan (perbuatan) yang "secara melawan hukum melakukan perbuatan memperkaya diri sendiri atau orang lain atau suatu korporasi" dan/atau tindakan atau perbuatan yang "bertujuan menguntungkan diri sendiri atau orang lain atau suatu korporasi, menyalahgunakan kewenangan, kesempatan atau sarana yang ada padanya karena jabatan atau kedudukan”. 
Terkait dengan kalimat "dapat merugikan keuangan negara atau perekonomian negara" sebagaimana tertuang dalam Pasal 2 ayat (1) dan Pasal 3 tersebut di atas, maka perlu diperhatikan Putusan Mahkamah Konstitusi Nomor: 25/PUU-XIV/2016, yang dalam pertimbangannya menegaskan, bahwa:

1. Bahwa kata "dapat" dalam Pasal 2 ayat (1) dan Pasal 3 UU Tipikor sebagaimana disebutkan di atas pernah diputus Mahkamah dalam Putusan Nomor 003/PUU-IV/2006, bertanggal 25 Juli 2006, dengan menyatakan tidak bertentangan dengan hak atas kepastian hukum yang adil sebagaimana dimaksudkan oleh Pasal 28D ayat (1) UUD 1945 sepanjang ditafsirkan sesuai dengan tafsiran Mahkamah (conditionally constitutional), yakni bahwa unsur kerugian negara harus dibuktikan dan harus dapat dihitung, meskipun sebagai perkiraan atau meskipun belum terjadi.

2. Bahwa berdasarkan Pasal 1 ayat (3) dan Pasal 28G ayat (1) UUD 1945 dan memperhatikan perkembangan pengaturan dan penerapan unsur merugikan keuangan negara sebagaimana diuraikan di atas, terdapat alasan yang mendasar bagi Mahkamah untuk mengubah penilaian konstitusionalitas dalam putusan sebelumnya, karena penilaian sebelumnya telah nyata secara berulang-ulang justru menimbulkan ketidakpastian hukum dan ketidakadilan dalam pemberantasan korupsi. Dengan demikian kata "dapat" dalam Pasal 2 ayat (1) dan Pasal 3 UU Tipikor bertentangan dengan UUD 1945 seperti yang didalilkan oleh para Pemohon beralasan menurut hukum;

3. Bahwa dengan keberadaan UU Administrasi Pemerintahan dikaitkan dengan kata "dapat" dalam Pasal 2 ayat (1) dan ayat (3) UU Tipikor menurut Mahkamah menyebabkan terjadinya pergeseran paradigma penerapan unsur merugikan keuangan negara dalam tindak pidana korupsi. Selama ini, berdasarkan Putusan Mahkamah Nomor 003/PUU-IV/2006 pemahaman kata "dapat" dalam Pasal 2 ayat (1) dan Pasal 3 UU Tipikor menyebabkan perbuatan yang akan dituntut di depan pengadilan bukan saja karena perbuatan tersebut "merugikan keuangan negara atau perekonomian negara secara nyata" akan tetapi hanya "dapat" menimbulkan kerugian saja pun sebagai kemungkinan atau potential loss, jika unsur perbuatan tindak pidana korupsi 
dipenuhi, sudah dapat diajukan ke depan pengadilan. Dalam perkembangannya dengan lahirnya UU Administrasi Pemerintahan maka kerugian negara karena kesalahan administratif bukan merupakan unsur tindak pidana korupsi. Kerugian negara menjadi unsur tindak pidana korupsi jika terdapat unsur melawan hukum dan penyalahgunaan kewenangan. Dalam hal adanya penyalahgunaan kewenangan, suatu perbuatan baru dapat diklasifikasikan sebagai tindak pidana korupsi apabila berimplikasi terhadap kerugian negara (kecuali untuk tindak pidana korupsi suap, gratifikasi atau pemerasan), pelaku diuntungkan secara melawan hukum, masyarakat tidak dilayani, dan perbuatan tersebut merupakan tindakan tercela. Dengan demikian bila dikaitkan dengan Pasal 2 ayat (1) dan Pasal 3 UU Tipikor, maka penerapan unsur merugikan keuangan negara telah bergeser dengan menitikberatkan pada adanya akibat, tidak lagi hanya perbuatan. Dengan perkataan lain kerugian negara merupakan implikasi dari: 1) adanya perbuatan melawan hukum yang menguntungkan diri sendiri atau orang lain atau suatu korporasi sebagaimana dimaksud dalam Pasal 2 ayat (1) UU Tipikor dan 2) penyalahgunaan kewenangan dengan tujuan menguntungkan diri sendiri atau orang lain atau suatu korporasi sebagaimana dimaksud dalam Pasal 3 UU Tipikor. Berdasarkan hal tersebut menurut Mahkamah unsur merugikan keuangan negara tidak lagi dipahami sebagai perkiraan (potential loss) namun harus dipahami benar-benar sudah terjadi atau nyata (actual loss) untuk dapat diterapkan dalam tindak pidana korupsi;

4. Bahwa pencantuman kata "dapat" dalam Pasal 2 ayat (1) dan Pasal 3 UU Tipikor membuat delik dalam kedua pasal tersebut menjadi delik formil. Hal itu menurut Mahkamah dalam praktik seringkali disalahgunakan untuk menjangkau banyak perbuatan yang diduga merugikan keuangan negara, termasuk terhadap kebijakan atau keputusan diskresi atau pelaksanaan asas freies ermessen yang diambil bersifat mendesak dan belum ditemukan landasan hukumnya, sehingga seringkali terjadi kriminalisasi dengan dugaan terjadinya penyalahgunaan wewenang. Demikian juga terhadap kebijakan yang terkait dengan bisnis namun dipandang dapat merugikan keuangan 
negara maka dengan pemahaman kedua pasal tersebut sebagai delik formil seringkali dikenakan tindak pidana korupsi. Kondisi tersebut tentu dapat menyebabkan pejabat publik takut mengambil suatu kebijakan atau khawatir kebijakan yang diambil akan dikenakan tindak pidana korupsi, sehingga di antaranya akan berdampak pada stagnasi proses penyelenggaraan negara, rendahnya penyerapan anggaran, dan terganggunya pertumbuhan investasi. Kriminalisasi kebijakan terjadi karena terdapat perbedaan pemaknaan kata "dapat" dalam unsur merugikan keuangan negara dalam tindak pidana korupsi oleh aparat penegak hukum, sehingga seringkali menimbulkan persoalan mulai dari perhitungan jumlah kerugian negara yang sesungguhnya sampai kepada lembaga manakah yang berwenang menghitung kerugian negara. Oleh karena dipraktikkan secara berbeda-beda menurut Mahkamah pencantuman kata "dapat" dalam Pasal 2 ayat (1) dan Pasal 3 UU Tipikor menimbulkan ketidakpastian hukum dan telah secara nyata bertentangan dengan jaminan bahwa setiap orang berhak atas rasa aman dan perlindungan dari ancaman ketakutan sebagaimana ditentukan dalam Pasal 28G ayat (1) UUD 1945. Selain itu, menurut Mahkamah kata "dapat” dalam Pasal 2 ayat (1) dan Pasal 3 UU Tipikor juga bertentangan dengan prinsip perumusan tindak pidana yang harus memenuhi prinsip hukum harus tertulis (lex scripta), harus ditafsirkan seperti yang dibaca (lex stricta), dan tidak multitafsir (lex certa), oleh karenanya bertentangan dengan prinsip negara hukum sebagaimana ditentukan dalam Pasal 1 ayat (3) UUD 1945.

5. Bahwa penerapan unsur merugikan keuangan dengan menggunakan konsepsi actual loss menurut Mahkamah lebih memberikan kepastian hukum yang adil dan bersesuaian dengan upaya sinkronisasi dan harmonisasi instrumen hukum nasional dan internasional, seperti dengan UU Administrasi Pemerintahan, Undang-undang Nomor 1 Tahun 2004 tentang Perbendaharaan Negara (UU Perbendaharaan Negara) dan Undang-undang Nomor 15 Tahun 2006 tentang Badan Pemeriksa Keuangan (UU BPK) serta Konvensi Perserikatan BangsaBangsa Anti Korupsi, 2003 (United Nation Convention Against Corruption, 2003) yang telah diratifikasi Indonesia melalui Undang-undang Nomor 7 
Tahun 2006. Pasal 1 angka 22 UU Perbendaharaan Negara dan Pasal 1 angka 15 UU BPK mendefinisikan, "Kerugian negara/Daerah adalah kekurangan uang, surat berharga, dan barang, yang nyata dan pasti jumlahnya sebagai akibat perbuatan melawan hukum baik sengaja maupun lalai”. Berdasarkan ketentuan tersebut konsepsi kerugian negara yang dianut adalah konsepsi kerugian negara dalam arti delik materiil, yakni suatu perbuatan dapat dikatakan merugikan keuangan negara dengan syarat harus adanya kerugian negara yang benar-benar nyata atau aktual. Konsepsi tersebut sebenarnya sama dengan penjelasan kalimat "secara nyata telah ada kerugian negara" yang tercantum dalam Pasal 32 ayat (1) UU Tipikor sebagaimana dijelaskan dalam Penjelasannya yang menyatakan sebagai kerugian yang sudah dapat dihitung jumlahnya berdasarkan hasil temuan instansi yang berwenang atau akuntan publik yang ditunjuk. Selain itu, agar tidak menyimpang dari semangat Konvensi PBB Anti Korupsi maka ketika memasukkan unsur kerugian negara dalam delik korupsi, kerugian negara tersebut harus benarbenar sudah terjadi atau nyata. Hal ini dikarenakan delik korupsi yang terdapat dalam Konvensi PBB Anti Korupsi telah diuraikan secara jelas meliputi suap, penggelapan dalam jabatan, memperdagangkan pengaruh, penyalahgunaan jabatan, pejabat publik memperkaya diri secara tidak sah, suap di sektor swasta, penggelapan dalam perusahaan swasta, pencucian uang hasil kejahatan, menyembunyikan adanya kejahatan korupsi, dan menghalanghalangi proses peradilan.

6. Bahwa berdasarkan Pasal 1 ayat (3) dan Pasal 28G ayat (1) UUD 1945 dan memperhatikan perkembangan pengaturan dan penerapan unsur merugikan keuangan negara sebagaimana diuraikan di atas, terdapat alasan yang mendasar bagi Mahkamah untuk mengubah penilaian konstitusionalitas dalam putusan sebelumnya, karena penilaian sebelumnya telah nyata secara berulang-ulang justru menimbulkan ketidakpastian hukum dan ketidakadilan dalam pemberantasan korupsi. Dengan demikian kata "dapat" dalam Pasal 2 ayat (1) dan Pasal 3 UU Tipikor bertentangan dengan UUD 1945 seperti yang didalilkan oleh para Pemohon beralasan menurut hukum; 
Berdasarkan pertimbangan sebagaimana tersebut di atas, Mahkamah Konstitusi membuat putusan yang tertuang dalam Putusan Mahkamah Konstitusi Nomor: 25/PUU-XIV/2016; sebagai berikut:

1. Mengabulkan permohonan para Pemohon untuk sebagian;

2. Menyatakan kata "dapat" dalam Pasal 2 ayat (1) dan Pasal 3 Undang-undang Nomor 31 Tahun 1999 tentang Pemberantasan Tindak Pidana Korupsi sebagaimana diubah dengan Undang-undang Nomor 20 Tahun 2001 tentang Perubahan Atas Undang-undang Nomor 31 Tahun 1999 tentang Pemberantasan Tindak Pidana Korupsi (Lembaran Negara Republik Indonesia Tahun 2001 Nomor 134, Tambahan Lembaran Negara Republik Indonesia Nomor 4150) bertentangan dengan Undang Undang Dasar Negara Republik Indonesia Tahun 1945 dan tidak mempunyai kekuatan hukum mengikat;

3. Menolak permohonan para Pemohon untuk selain dan selebihnya; serta

4. Memerintahkan pemuatan Putusan ini dalam Berita Negara Republik Indonesia sebagaimana mestinya;

Sesuai dengan pertimbangan dan amar putusan Mahkamah Konsititusi sebagaimana diuraikan di atas, maka unsur dapat merugikan keuangan negara atau perekonomian negara, harus diukur secara riil atau nyata, dengan kata lain kerugian tersebut benar-benar telah terjadi, sedangkan dalam pelaksanaan perjanjian kerjasama pada PT. Tanjungpinang Makmur Bersama (BUMD di Kota Tanjungpinang), kerugian keuangan negara belum terjadi karena pelaksanaan perjanjian yang pernah terkendala, ternyata masih tetap dilanjutkan, selain itu kendala yang dihadapi tidak karena adanya kesalahan atau kelalaian dalam manajemen PT. Tanjungpinang Makmur Bersama (BUMD di Kota Tanjungpinang), atau dengan kata lain tidak memenuhi unsur melawan hukum dan/atau unsur yang bertujuan untuk menguntungkan diri sendiri atau orang lain atau suatu korporasi

\section{E. Kesimpulan}

Berdasarkan hasil analisis yang dilakukan, maka dapat disimpulkan halhal sebagai berikut: 
1. Perjanjian kerjasama penyertaan modal (investasi) pengadaan tower telekomunikasi pada P.T. Tanjungpinang Makmur Bersama (BUMD Kota Tanjungpinang) adalah perbuatan hukum dan hubungan hukum yang termasuk dalam lapangan hukum perdata.

2. Terlambatnya pelaksanaan perjanjian kerjasama penyertaan modal (investasi) pengadaan tower telekomunikasi pada P.T. Tanjungpinang Makmur Bersama (BUMD Kota Tanjungpinang), tidak merupakan kesalahan Saudara Eva Amalia sebagai Direktur pada tahun 2012 sampai dengan tahun 2014, yang telah beritikad dalam menjalankan perusahaan, melainkan karena adanya kendala internal dan eksternal dalam pelaksanaan perjanjian, sehingga pertanggungjawaban perdata maupun pidana tidak dapat dimintakan kepadanya secara personal (pribadi).

3. Keterlambatan dalam pelaksanaan perjanjian kerjasama penyertaan modal (investasi) pengadaan tower telekomunikasi pada P.T. Tanjungpinang Makmur Bersama (BUMD Kota Tanjungpinang), belum dapat dikatakan telah mengakibat kerugian keuangan negara atau perekonomian negara, karena perjanjian tersebut masih tetap berlangsung.

4. Keterlambatan dalam pelaksanaan perjanjian kerjasama penyertaan modal (investasi) pengadaan tower telekomunikasi pada P.T. Tanjungpinang Makmur Bersama (BUMD Kota Tanjungpinang), tidak memenuhi unsurunsur untuk dikatakan sebagai tindak pidana korupsi. 


\section{DAFTAR PUSTAKA}

\section{Buku:}

Bambang Sunggono. 1998. Metodologi Penelitian Hukum. Cetakan Kedua. Jakarta: RajaGrafindo Persada,

Johny Ibrahim. 2006. Teori dan Metodologi Penelitian Hukum Normatif. Cetakan Kedua. Malang: Bayumedia Publishing.

Miriam Budiardjo. 2008. Dasar-dasar Ilmu Politik. Edisi Revisi. Jakarta: Gramedia.

Ridwan HR. 2006. Hukum Administrasi Negara. Jakarta: PT. RajaGrafindo Persada.

Salim HS dan Erlies Septiana Nurbaini. 2013. Penerapan Teori Hukum pada Penelitian Tesis dan Disertasi. Jakarta: RajaGrafindo Persada.

Soerjono Soekanto dan Sri Mamudji. 2003. Penelitian Hukum Normatif, Suatu Tinjauan Singkat. Cetakan Keenam. Jakarta: RadaGrafindo Persada.

Soerjono Soekanto. 2012. Pengantar Penelitian Hukum. Cetakan Ketiga. Jakarta: UI-Press.

Subekti, R. 2004. Kitab Undang-undang Hukum Perdata (KUHPerdata). Jakarta: Pradya Paramita.

Zainuddin Ali. 2011. Metode Penelitian Hukum. Jakarta: Sinar Grafika.

\section{Jurnal:}

Alfitri. 2012. "Ideologi Welfare State dalam Dasar Negara Indonesia: Analisis Putusan Mahkamah Konstitusi terkait Sistem Jaminan Sosial Nasional". Jurnal Konstitusi. Volume 9. Nomor 3. September. Jakarta: Mahkamah Konstitusi.

\section{Peraturan Perundang-undangan:}

Republik Indonesia, Undang Undang Dasar Tahun 1945.

Republik Indonesia, Undang-undang Nomor 5 Tahun 1962 tentang Perusahaan Daerah.

Republik Indonesia, Undang-undang Nomor 20 Tahun 2001 tentang Perubahan Atas Undang-undang Nomor 31 Tahun 1999 tentang Pemberantasan Tindak Pidana Korupsi. 
Republik Indonesia, Undang-undang Nomor 19 Tahun 2003 tentang Badan Usaha Milik Negara.

Republik Indonesia, Undang-undang Nomor 1 Tahun 2004 tentang Perbendaharaan Negara

Republik Indonesia, Undang-undang Nomor 15 Tahun 2006 tentang Badan Pemeriksa Keuangan.

Republik Indonesia, Undang-undang Nomor 40 Tahun 2007 tentang Perseroan Terbatas.

Republik Indonesia, Undang-undang Nomor 23 Tahun 2014 tentang Pemerintahan Daerah.

Republik Indonesia, Putusan Mahkamah Konstitusi Nomor: 25/PUU-XIV/2016.

Peraturan Daerah Kota Tanjungpinang, Nomor 4 Tahun 2007 tentang Badan Usaha Milik Daerah.

Peraturan Daerah Kota Tanjungpinang Nomor 7 Tahun 2011 tentang Penyertaan Modal Pemerintah Kota Tanjungpinang pada PT. Bank Riau KEPRI, PT. Riau Air Lines, Perusahaan Daerah Bank Perkreditan Rakyat Bestari, dan PT. Tanjungpinang Makmur Bersama

\section{Internet:}

Oman Sukmana. "Konsep dan Desain Negara Kesejahteraan (Welfare State)", http://osukmana.blogspot.co.id., diakses tanggal 12 Pebruari 2017. 


\section{BIODATA PENULIS}

$\begin{array}{ll}\text { Nama } & \text { : Dr. Tengku Erwinsyahbana, S.H., M.Hum } \\ \text { Pekerjaan } & \text { : Dosen Fakultas Hukum Universitas Muhammadiyah Sumatera } \\ & \text { Utara } \\ \text { Jabatan } & : \text { Lektor } \\ \text { Nomor HP } & : \text { 081397622420 } \\ \text { E-mail } & : \text { erwin6768@gmail.com } \\ \text { Alamat Kantor } & : \text { Jl. Kapten Muchtar Basri No. 3, Medan }\end{array}$ 